\title{
To investigate the effect of Cassia fistula powder on the growth performance and health of broiler
}

Sarfiraz Ali Depar ${ }^{1}$, Imdad Hussain Lighari ${ }^{1 *}$, Nasir Rajput ${ }^{1}$, Muhammad Naeem Rajput ${ }^{2}$, Muhammad Azhar Memon ${ }^{3}$, Ahmed Ali Moryani ${ }^{1}$, Muhammad Bilawal Arain, Ali Gul Soomro ${ }^{4}$, Muhammad Qasim Mazari $^{5}$, Chandni Wajid $^{6}$, Sambreena Tunio ${ }^{7}$ and Teerath Ram Bheermani $^{8}$

1. Department of Poultry Husbandry, Sindh Agriculture University Tando Jam-Pakistan

2. Department of Livestock Management, Sindh Agriculture University, Tando Jam-Pakistan

3. Department of Veterinary Parasitology, Sindh Agriculture University Tando Jam-Pakistan

4. Department of Veterinary Pharmacology, Sindh Agriculture University Tando Jam-Pakistan

5. Department of Veterinary Microbiology, Sindh Agriculture University, Tando Jam-Pakistan

6. Department of Animal Breeding and Genetics, LUAWMS, Uthal, Balochistan-Pakistan

7. Department of Animal Product Technology, Sindh Agriculture University, Tando Jam-Pakistan

8. Department of Animal Nutrition, Sindh Agriculture University, Tando Jam-Pakistan

*Corresponding author's email: imdadleghari@hotmail.com

\section{Citation}

Sarfiraz Ali Depar, Imdad Hussain Lighari, Nasir Rajput, Muhammad Naeem Rajput, Muhammad Azhar Memon, Ahmed Ali Moryani, Muhammad Bilawal Arain, Ali Gul Soomro, Muhammad Qasim Mazari, Chandni Wajid, Sambreena Tunio and Teerath Ram Bheermani. To investigate the effect of Cassia fistula powder on the growth performance and health of broiler. Pure and Applied Biology. Vol. 10, Issue 4, pp945-955.

http://dx.doi.org/10.19045/bspab.2021.100098

\begin{tabular}{llll}
\hline \hline Received: 01/10/2020 & Revised: 18/12/2020 & Accepted: 24/12/2020 & Online First: 02/01/2021 \\
\hline \hline
\end{tabular}

\section{Abstract}

Cassia fistula is an ornamental plant which is belong from family Fabaceae family known as" Golden Rain Tree" which have medicinal and nutritive values. The present study was conducted to investigate the effect of Cassia fistula on the growth performance and health of broilers. One hundred eighty (180) day old broiler chicks were purchased from local hatchery and divided into the six groups, i.e., group A (commercial diet), group B (basal diet) were control, group C (Basal diet with Cassia fistula powder $250 \mathrm{mg} / \mathrm{kg}$ in starter phase), group D (basal diet with Cassia fistula powder $250 \mathrm{mg} / \mathrm{kg}$ in finisher phase), group E (commercial diet with Cassia fistula $250 \mathrm{mg} / \mathrm{kg}$ in starter phase) and group F (commercial diet with Cassia fistula $250 \mathrm{mg} / \mathrm{kg}$ in finisher phase) respectively. The result showed significant difference in weight gain $(2036.7 \mathrm{~g}, 1997.7 \mathrm{~g}, 2263.3 \mathrm{~g}, 2161.3 \mathrm{~g}$, $2342.3 \mathrm{~g}$ and $2193.3 \mathrm{~g}$ ), feed intake $(4451.3 \mathrm{~g}, 4201.7 \mathrm{~g}, 4182.3 \mathrm{~g}, 3836.7 \mathrm{~g}, 3942.7 \mathrm{~g}$ and $4368.3 \mathrm{~g}$ ) and FCR $(2.16,2.06,1.83,1.76,1.63$ and 1.96) was recorded in group A, B, C, D, E, and F respectively. A non-significant difference in dressing $\%(61.77 \%, 64.15 \%, 63.43 \%, 63.38 \%, 66.47 \%$ and $65.94 \%)$ was recorded in group A, B, C, D, E and F respectively. Additionally, a non-significant difference in mortality $\%(4 \%, 2 \%, 3.3 \%, 2.6 \%, 0.3 \%$ and $1.6 \%)$ and visceral organ such as relative weight of heart $(0.65 \%, 0.62 \%, 0.58 \%, 0.58,0.57 \%$ and $0.59 \%)$, spleen $(0.08 \%, 0.08 \%, 0.07 \%, 0.07 \%, 0.06 \%$ and 
$0.06 \%$ ) was recorded in group A, B, C, D, E, and F respectively. Thus, it is concluded that Cassia fistula@250 mg/kg with commercial diet (group-E) supplementation in broiler ration showed optimum results in terms of body weight gain, Feed intake, FCR, dressing (\%) and it has preventive properties.

Keywords: Broiler; Cassia Fistula; Growth performance; Health

\section{Introduction}

Cassia fistula is an ornamental plant which is belong from family Fabaceae known as" Golden Rain Tree" which have medicinal and nutritive values. Moreover, it is enriched with variety of naturally occurring bioactive compounds, which are larger extent secondary metabolite and being incorporated in medicines, food supplements and in miscellaneous commercial products [1] The chemical composition of Cassia fistula contains alkaloids, tannins, flavonoids, anthraquinone, terpenes, sugars, glucosides and biological active compounds 5nonatetracontanone, 2- hentriacontane, triacontane, hentriacontanol and sitosterol (Antibacterial). It has been reported that tannins which are naturally occurring and water-soluble phenolic compounds and help in protein precipitation from aqueous media are abundantly present in Cassia fistula [2]. Moreover, it has indicated that Cassia fistula has abundant glycosides that are used to boost the cardiac contractile force in patient with pulmonary hypertension and have significant effects in the cancer therapy [3]

Health of broiler is extremely important which play significant role for the better growth performance and digestion. The fruit of Cassia fistula have antidiabetic [4], antipyretic abortifacient, demulcent, antiinflammatory properties used against pulmonary congestion, throat liver complaints, disease of eyes and gripin [5], leave have anti-inflammatory, antipyretic and cathartic properties used in dermatology, gouty arthritis, ulcer and boils. Moreover, its roots, leaves and pods have astringent purgative tonic properties therefore used in constipation $[6,1]$ and its metabolites, biological active compound and seed powder have antibacterial, fungicidal, anthelmintic, hepatorotective and muscle relaxant activity and also antamebic properties [7,8] therefore used as feed additive in the poultry feed in order to decrease the outbreak of bacterial disease result to improve the growth performance [9] and used against intestinal disorder [10]. It is effective against gram positive and gram-negative bacteria species such as Klebsiella aerogenes, Mycobacterium smegmatis, Proteus vulgaris, Pseudomonas aerogenes, Bacillus subtilis, Bacillus mycoides and E. coli [11] It has been examined that feed which is contaminated with fungus cause mortality and morbidity in broiler, when Cassia fistula was used in feed resulted in reduced fungal contamination because of its antifungal property and hence increased growth performance of birds [7] It has been observed that helminths have negative effect upon growth performance due to destruction of gastro intestinal tract, which leads to reduced digestibility of broiler. It has been reported that methanolic extract of Cassia fistula fruit pulp and seeds showed significant anthelmintic activity. The extract paralyzed and killed the worms in a very short time at dose of $100 \mathrm{mg} / \mathrm{ml}$ [12].

Moreover, plant is used as curative agent in the therapy of hypercholesterolemia particularly their fiber and mucilage content [14]. Antioxidant activity of Cassia fistula is correlated with polyphenolic content of pulp, flower, leaves and stem bark [15] Chemical composition of fresh leaves contains: crude protein $18 \mathrm{~g}$, crude fiber $30 \mathrm{~g}$, Ash $8 \mathrm{~g}$, ether extracts $8 \mathrm{~g}$ and nitrogen free extract $37 \mathrm{~g}$. The detailed biochemical analysis of flowers pollen is composed of $12 \%$ protein, $11.75 \%$ carbohydrate, $12 \%$ lipid and $1.42 \%$ free 
amino acid [16]. It was concluded that the fruit of Cassia fistula is of high quality and could be explored to fulfill the nutrient and requirements that are necessary for broiler because it contain enough amount of macro and micro nutrient which enhanced the growth performance of broiler [17]. It has been reported that Cassia fistula meal are used as a replacement of soya bean meal in diets, from the result of their study, it was revealed that the nutrient utilization and growth performance of animals fed up to $170 \mathrm{~g} / \mathrm{kg}$ of Cassia fistula seed as a meal could be substituted for soya bean meal in practical diets without expressing growth [18].

The objectives of present study was to identify the effect of medicinal plant, Cassia fistula on the growth performance, feed efficiency and health of commercial broiler chicken which will be beneficial for the poultry industry.

Table 1. Grouping of birds and treatment

\begin{tabular}{|c|c|c|c|c|c|c|}
\hline \multirow{4}{*}{ Group } & A & B & C & D & E & F \\
\cline { 2 - 6 } & \multicolumn{2}{|c|}{ Control } & $\begin{array}{c}\text { Basal diet } \\
+ \text { Cassia } \\
\text { Distula } \\
\text { Dowercial }\end{array}$ & $\begin{array}{c}\text { Basal } \\
\text { diet } \\
+ \text { Cassia } \\
\text { fistula } \\
\text { Powder }\end{array}$ & $\begin{array}{c}\text { Commercial } \\
\text { diet + Cassia } \\
\text { fistula } \\
\text { Powder }\end{array}$ & $\begin{array}{c}\text { Commercial } \\
\text { diet + Cassia } \\
\text { fistula } \\
\text { Powder }\end{array}$ \\
\hline $\begin{array}{c}\text { Starter } \\
\text { Supplementation }\end{array}$ & 0 & 0 & $250 \mathrm{mg} / \mathrm{kg}$ & 0 & $250 \mathrm{mg} / \mathrm{kg}$ & 0 \\
\hline $\begin{array}{c}\text { Finisher } \\
\text { supplementation }\end{array}$ & 0 & 0 & 0 & $\begin{array}{c}250 \mathrm{mg} / \mathrm{k} \\
\mathrm{g}\end{array}$ & 0 & $250 \mathrm{mg} / \mathrm{kg}$ \\
\hline
\end{tabular}

\section{Housing management}

The poultry house was entirely cleaned, washed and sanitized. The birds were kept on deep litter housing system. Temperature was maintained around $95^{\circ} \mathrm{F}$ at first week and then temperature was gradually reduced by $5^{\circ} \mathrm{F}$ per week until it reached around $70^{\circ} \mathrm{F}$. Relative humidity was maintained around 55 to 65

\section{Materials and Methods}

One hundred eighty (180) day old chicks were bought from commercial hatchery and taken to Poultry Research Station, Sindh Agriculture University, Tandojam.

\section{Experimental design}

Cassia fistula powder was purchased from folk medicine store Hyderabad. Birds were divided into six groups with 3 replicates, each replicate contain 10 chicks. However, group A and B were control, Group A fed with commercial diet. Group $\mathrm{C}$ was supplemented with Cassia fistula powder at the dose of 250 $\mathrm{mg} / \mathrm{kg}$ in basal diet in starter phase. Group D was supplemented with Cassia fistula powder at the dose of $250 \mathrm{mg} / \mathrm{kg}$ in basal diet in finisher phase. Group E was supplemented with Cassia fistula powder at the dose of 250 $\mathrm{mg} / \mathrm{kg}$ in commercial diet in starter phase. Group F was supplemented with Cassia fistula at the dose of $250 \mathrm{mg} / \mathrm{kg}$ in commercial diet in finisher phase. Moreover, the fresh water was provided ad libitum and feeding program was consist of a two phases starter diet (0-21 days) and finisher diet (22-42 days). 


\section{Vaccination program}

The following vaccination program were adopting according to the recommendation of
Poultry Department Sindh Agriculture University Tandojam.

Table 2. Vaccinations

\begin{tabular}{|c|c|c|}
\hline Days & Vaccines & Route \\
\hline $3^{\text {rd }}$ & Newcastle disease + Infectious Bronchitis. & Intraocular (E/D) \\
\hline $10^{\text {th }}$ & Infectious Bursal Disease & Drinking water \\
\hline $21^{\text {th }}$ & Newcastle Disease & Drinking water \\
\hline $28^{\text {th }}$ & Infectious Bursal Disease & Drinking water \\
\hline
\end{tabular}

\section{Parameter to be studied}

Weight gain, Feed intake, Feed conversion ratio (FCR), Dressing\%, Mortality (\%), and weight of non-edible organ (Heart and Spleen) were studied in this experiment which are related to the growth performance of broiler chicken.

\section{Parameters recording procedure Weight gain}

After arrival of day-old broiler chicks at Poultry Experimental Station, individual chick was weighed by using electric weighing scale and later chicks were weighed at the end of each week.

\section{Feed intake}

Fresh feed was provided two times daily and then refusal feed was collected from each group, weighed and finally the consumed feed was calculated. The following formula was used:

Feed intake $(\mathrm{g} / \mathrm{b})=\underline{\text { Total feed offered }- \text { Total feed refused }}$ Total no of broiler

\section{Feed conversion ratio (FCR)}

Feed conversion ratio was obtained on the basis of total feed intake by birds for gaining body weight. The following formula was used;

FCR $=$ Total feed intake

Total live body weight

\section{Dressing percentage}

Three broilers from each group were weighed and slaughtered at the end of experimental period (42) days. After, that the carcass weight was recorded and then its dressing percentage was calculated by the following formula.

Dressing $(\%)=\underline{\text { Total carcass weight }(\mathrm{kg})}$ X100

Mortality (\%)

Total live body weight

During the entire work of research, the dead birds were collected, and mortality was recorded and finally the mortality (\%) was calculated by following formula:

$$
\text { Mortality }(\%)=\underline{\text { Total No. of Birds Died }} \text { X100 }
$$

\section{Weight of non-edible organs}

At the end of trail, the three broilers were slaughtered from each group, the following organs such as heart and spleen were removed with the help of scalpel and scissor and weighed by electric weighing balance to see the effect of cassia fistula on these non-edible organs.

\section{Data analysis}

The final data was analyzed through the statistical tool, Analysis of variance (ANOVA) the level of significance at $\mathrm{a}=0.05$. Moreover, the significance difference was noticed among the means of all groups then least significance difference (L.S.D) was done by using a standard statistical computer package `Statistixver` 8.1 .

\section{Results}

Supplement of Cassia fistula in different groups was examined and statistical outcomes of the obtained data are presented given below. 


\section{Weight gain (g/b)}

The result shows that highest values for weight gain $(2342.3 \pm 38.87 \mathrm{~g} / \mathrm{b})$ was calculated from the birds reared in group-E, followed by group C $(2263.3 \pm 65.82 \mathrm{~g} / \mathrm{b})$, D $(2161.3 \pm 20.66 \mathrm{~g} / \mathrm{b}), \mathrm{F}(2193.3 \pm 47.63 \mathrm{~g} / \mathrm{b})$ and
A $(2036.7 \pm 34.83 \mathrm{~g} / \mathrm{b}), \quad$ correspondingly. Additionally, lowest weight gain $(1997.7 \pm 52.65 \mathrm{~g} / \mathrm{b})$ was noted in group B. A significant $(\mathrm{p}<0.05)$ variation in weight gain was noticed among all group (Fig. 1).

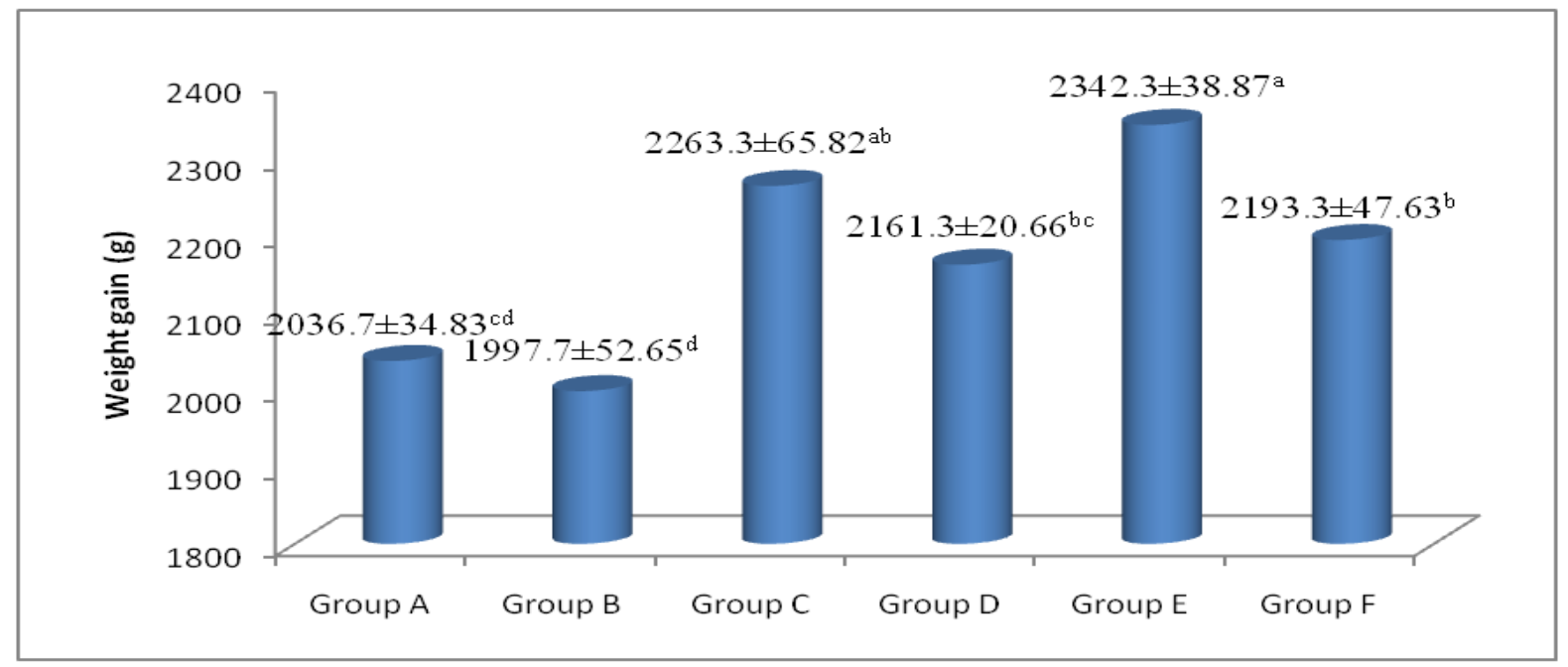

abcd superscripts showed $\mathrm{p}$-value $=0.0014$ significance difference at $(\mathrm{P}<0.05)$

Figure 1. Effect of Cassia fistula supplementation on weight gain (g/b)

Feed intake $(\mathrm{g} / \mathrm{b})$

The result shows that, the highest values for feed intake $(4451.3 \pm 125.09 \mathrm{~g} / \mathrm{b})$ was calculated from the birds reared in group-A, F $(4368.3 \pm 175.57 \mathrm{~g} / \mathrm{b})$, B $(4201.7 \pm 136.18$ $\mathrm{g} / \mathrm{b}), \quad \mathrm{C} \quad(4182.3 \pm 55.54 \mathrm{~g} / \mathrm{b})$ and $\mathrm{E}$ $(3942.7 \pm 188.7 \mathrm{~g} / \mathrm{b})$ respectively. Lowest value of feed intake $(3836.7 \pm 77.90 \mathrm{~g} / \mathrm{b})$ was noted in D group. Moreover, significant $(\mathrm{p}<0.05)$ variation in feed intake was noticed among group (A, F) and (D, E,). While, (B and $\mathrm{C}$ ) and $(\mathrm{E}$ and $\mathrm{F})$ were non-significantly different from one another (Fig. 2).

\section{Feed conversion ratio (FCR)}

The result shows that, comparatively better FCR (1.6333 \pm 0.03$)$ was calculated from the birds reared in group-E than $F(1.9667 \pm 0.06$ $\mathrm{g} / \mathrm{b}), \mathrm{C}(1.8333 \pm 0.03)$ and $\mathrm{D}(1.7667 \pm 0.08$ g/b), correspondingly. Poor FCR was obtained from group A and B $(2.1667 \pm 0.03$ and 2.0667 \pm 0.12$)$. A significant $(\mathrm{p}<0.05)$ variation in FCR was noticed for group (A, B) with (C, D, E and F). While, (A, B) and (C and $\mathrm{F}$ ) group were non-significantly different from each another (Fig. 3).

\section{Dressing (\%)}

The result shows that, the highest values for dressing $(66.473 \pm 0.48 \%)$ was calculated from the birds reared in group-E than $\mathrm{F}$ $(65.947 \pm 0.94 \%), \quad$ B $(64.153 \pm 1.58 \%), \quad$ C $(63.48 \pm 2.04 \%)$ and D $(63.38 \pm 2.51 \%)$, correspondingly. Lowest value of dressing $(61.773 \pm 1.08 \%)$ was noted in A group. A non-significant $(\mathrm{p}>0.05)$ variation in dressing percentage was noticed in all groups (Fig. 4). 


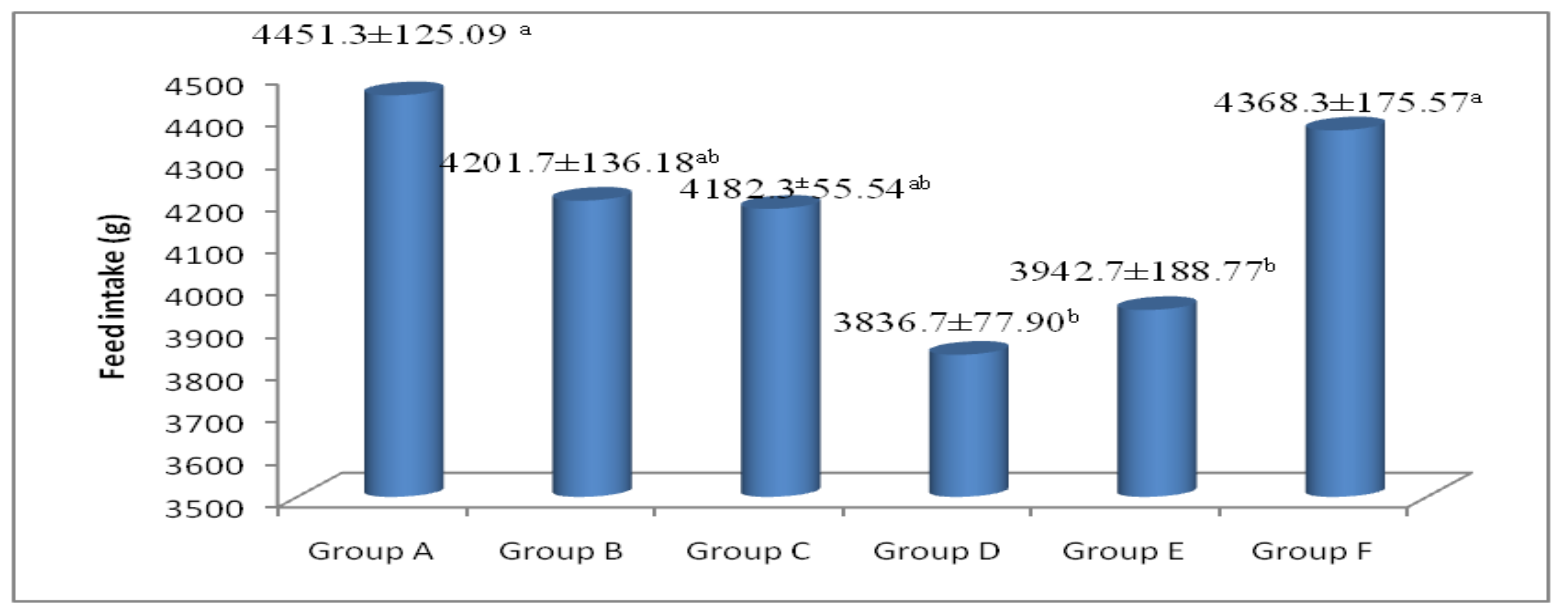

ab superscripts showed $\mathrm{p}$-value $=0.0510$ significance difference at $(\mathrm{P}<0.05)$

Figure 2. Effect of Cassia fistula supplementation on feed intake (g/b)

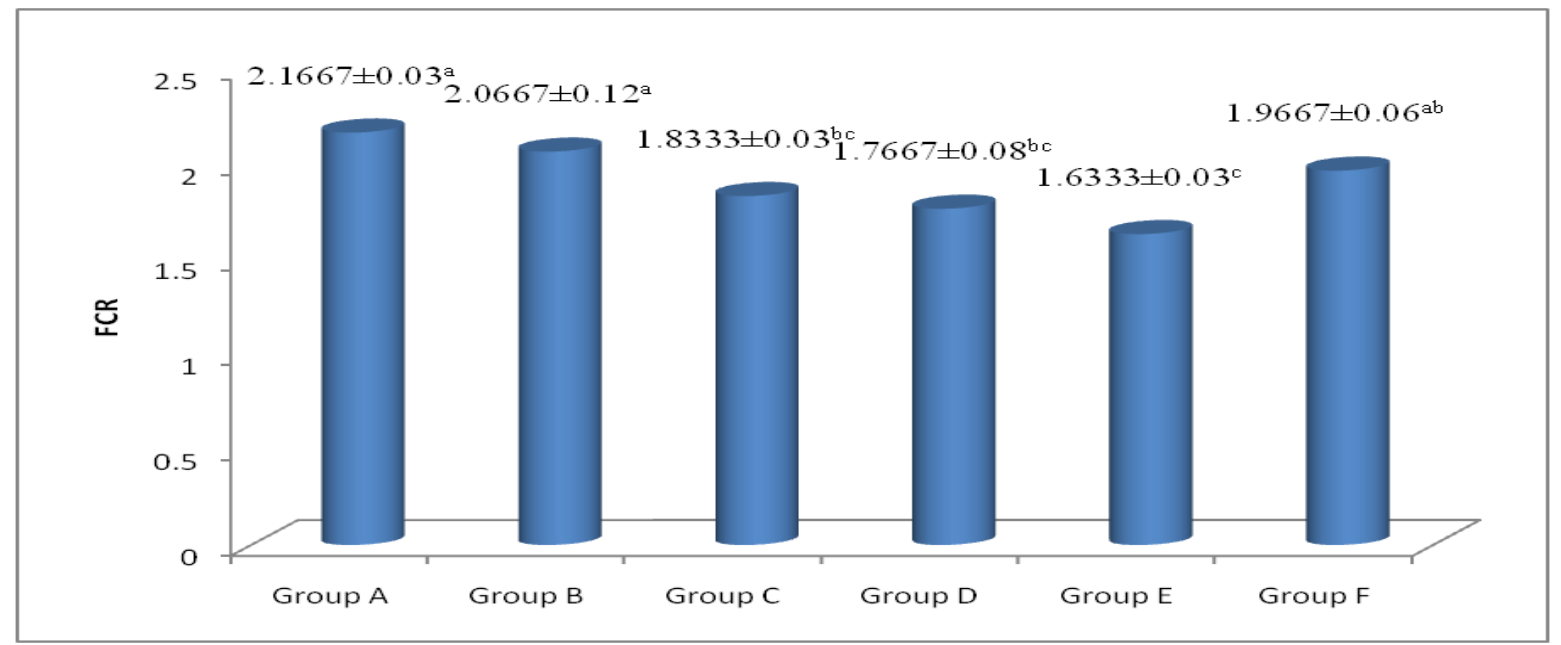

abc superscripts showed p-value $=0.0017$ significance difference at $(\mathrm{P}<0.05)$

Figure 3. Effect of Cassia fistula supplementation on FCR

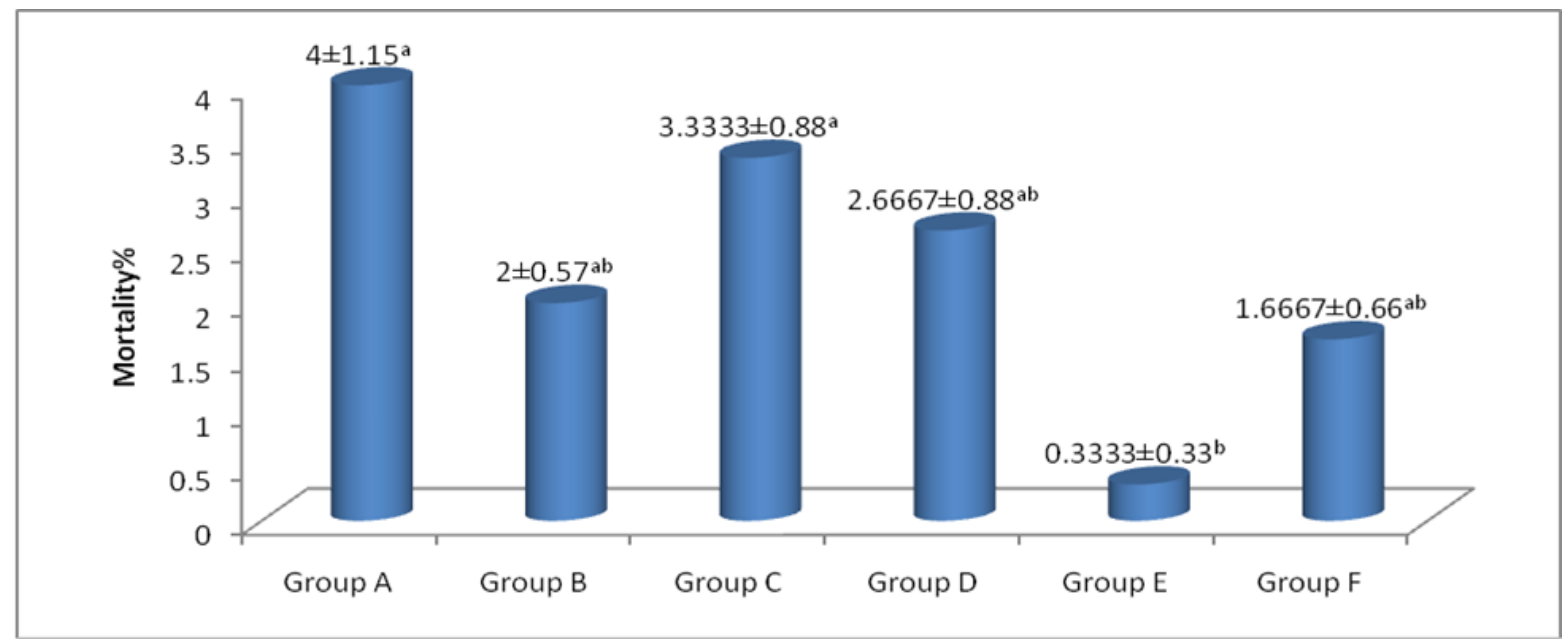

P-value $=0.3648, \mathrm{NS}=$ Non significant

Figure 4. Effect of Cassia fistula supplementation on dressing (\%) 


\section{Mortality (\%)}

The result shows that, the highest values for mortality $(4 \pm 1.15 \%)$ was calculated from the birds reared in group-A than $\mathrm{C}$ $(3.3333 \pm 0.88 \%), \quad \mathrm{D} \quad(2.6667 \pm 0.88 \%), \quad \mathrm{B}$ $(2 \pm 0.57 \%)$ and F $(1.6667 \pm 0.66 \%)$, correspondingly. Lowest value of mortality $(0.3333 \pm 0.33 \%)$ was noted in $\mathrm{E}$ group. A significant $(\mathrm{p}<0.05)$ variation in mortality percentage was noticed for group $(\mathrm{A}, \mathrm{C})$ with $(\mathrm{B}, \mathrm{D}, \mathrm{E}, \mathrm{F})$. While, group $(\mathrm{B}, \mathrm{D}, \mathrm{F})$ were nonsignificantly different from one another (Fig. $5)$.

\section{Relative weight of heart (\%)}

The result shows that, the highest values for relative weight of heart $(0.6531 \pm 0.22 \%)$ was calculated from the birds reared in group-A than B $(0.6298 \pm 0.01 \%), F(0.5928 \pm 0.01 \%)$, $\mathrm{D}(0.5892 \pm 0.01 \%)$ and $\mathrm{C}(0.5889 \pm 0.01 \%)$, correspondingly. Lowest value of relative weight of heart $(0.5793 \pm 0.01 \%)$ was noted in E group. A significant $(\mathrm{p}<0.05)$ variation in relative weight of heart was noticed for group (A and B). While, group (C, D, E and F) was non-significantly different from one another (Fig. 6).

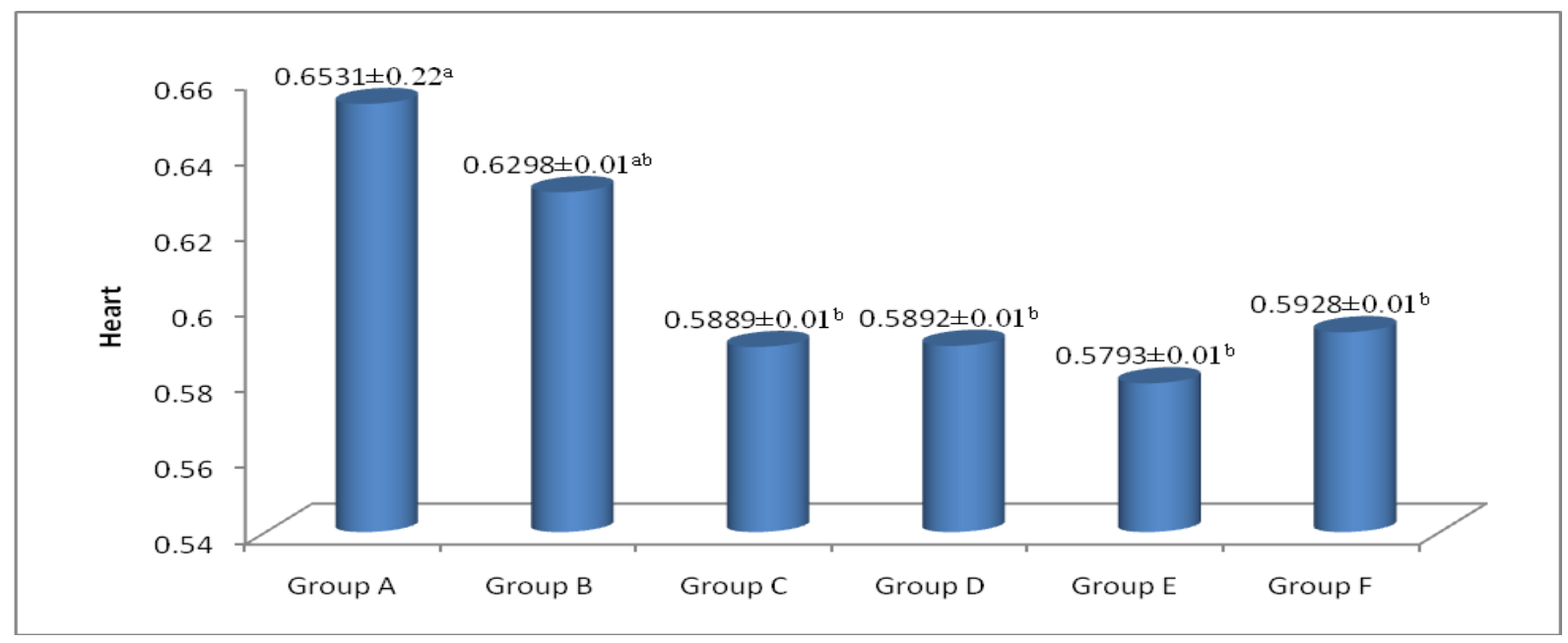

ab superscripts showed $\mathrm{p}$-value $=0.0749$ significance difference at $(\mathrm{P}<0.05)$

Figure 5. Effect of Cassia fistula supplementation on mortality (\%)

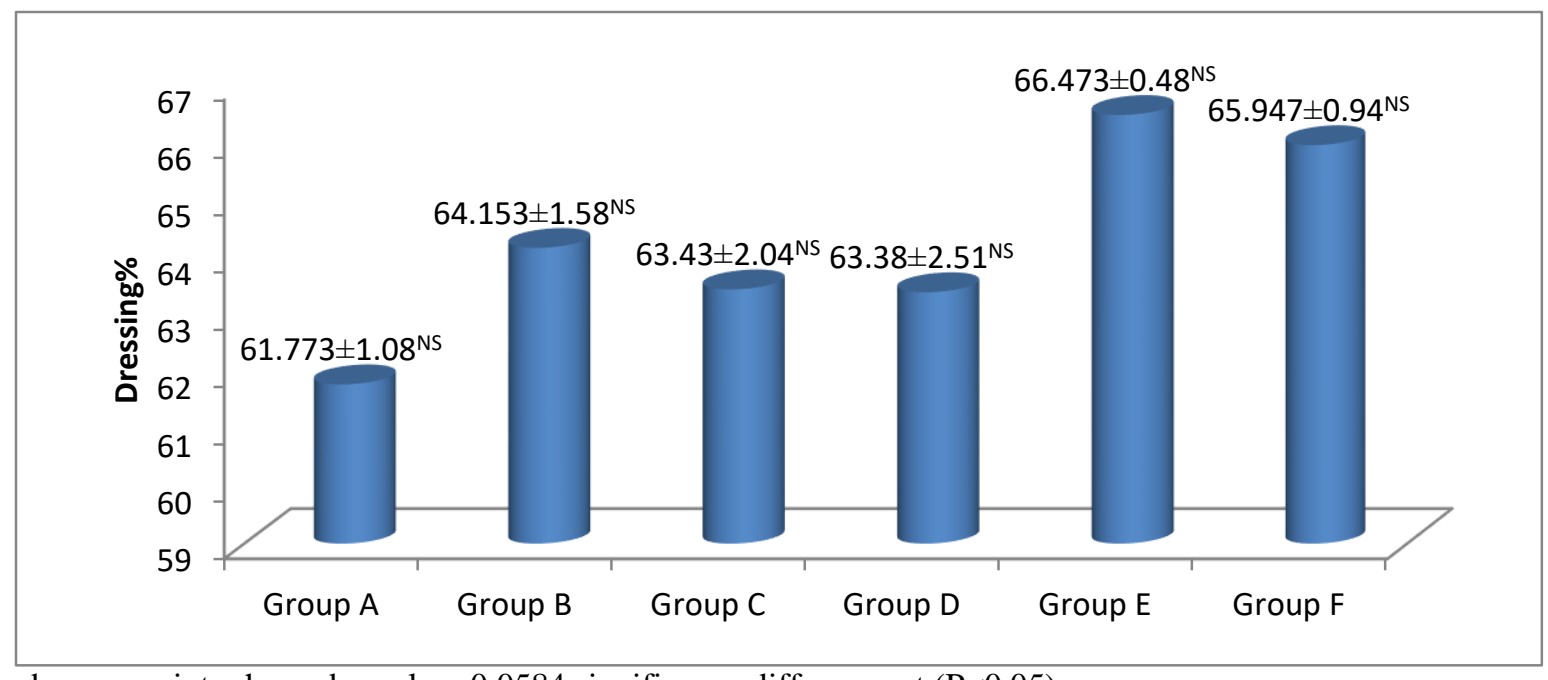

ab superscripts showed $\mathrm{p}$-value $=0.0584$ significance difference at $(\mathrm{P}<0.05)$

Figure 6. Effect of Cassia fistula supplementation on relative weight of heart (\%) 
Relative weight of spleen (\%)

The result shows that, the highest values for relative weight of spleen $(0.0838 \pm 8.85 \%)$ was calculated from the birds reared in group-B than A $(0.0808 \pm 8.96 \%), \quad \mathrm{C}$ $(0.0791 \pm 9.81 \%), \mathrm{D}(0.0727 \pm 0.01 \%)$ and $\mathrm{E}$
(0.0672 $\pm 5.47 \%)$, correspondingly. Lowest value of relative weight of spleen $(0.0652 \pm 3.00 \%)$ was noted in $\mathrm{F}$ group. A non-significant $(p>0.05)$ variation in relative weight of spleen was noticed between all groups (Fig. 7).

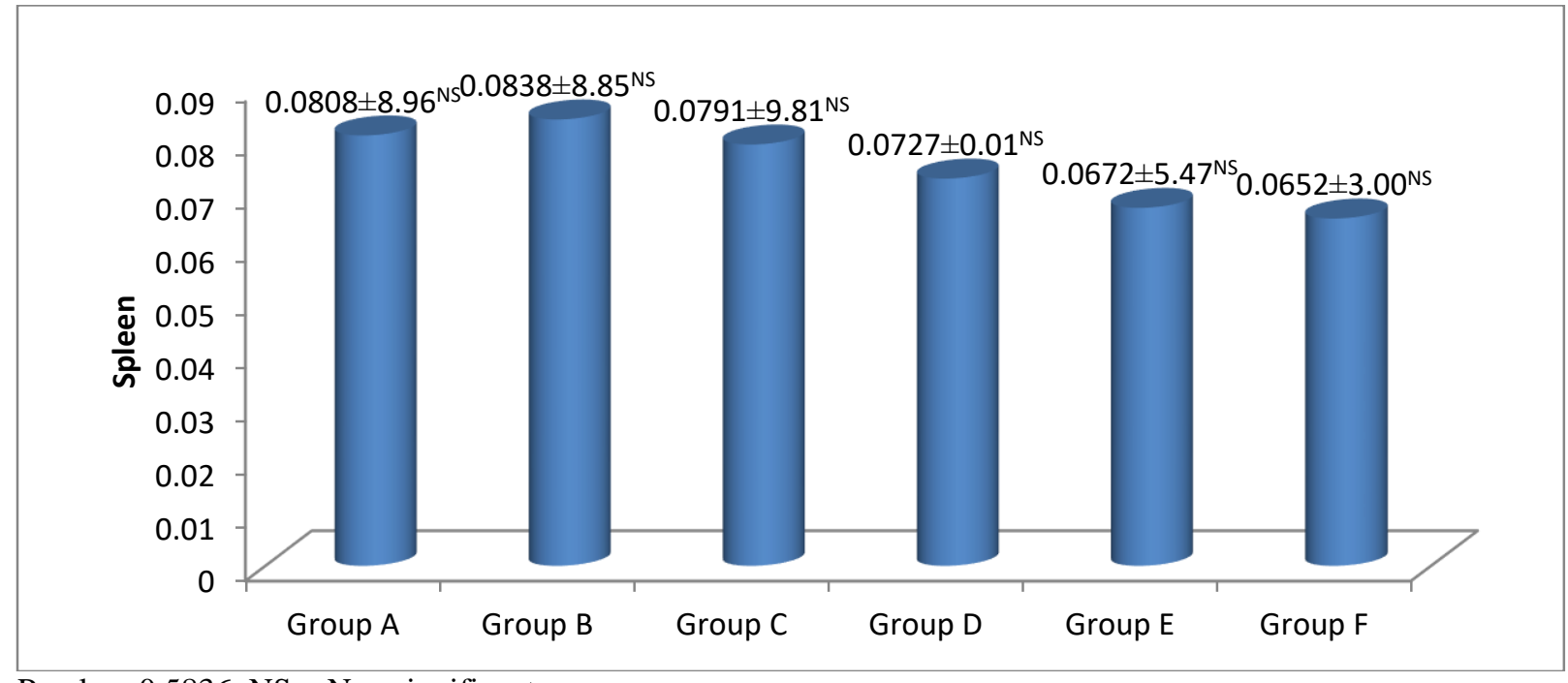

$\mathrm{P}$-value $=0.5836, \mathrm{NS}=$ Non significant

Figure 7. Effect of Cassia fistula supplementation on relative weight of spleen (\%)

\section{Discussion}

In current study, birds supplemented with Cassia fistula in commercial diet at starter phase resulted highest weight gain in comparison to control group. Our findings are agreement with [3], who stated that herbs possess the biological activities which have growth stimulating effect in broilers, thus herbs can be used as feed additive and as a growth promoter. However, the feed additives are non-nutritive substances which are used in the poultry feed such as antioxidant, enzymes, pellet binders, flavoring agent and antibiotics which are beneficial for the growth rate of broilers [4].

\section{Weight gain}

Present results are related with the results of [5] who reported that Cassia fistula has positive effect on the growth performance and weight gain which increased significantly when diet with 3, 5 and $7 \%$ Cassia fistula powder supplementation in comparison to control group. In spite of lack of literature on the usage of Cassia fistula as antibiotic growth promoter, [6] has suggested Cassia fistula powder may be used as growth promoters for broiler production [7] reported that it has beneficial effect on growth due to it enough amounts of macro and micro nutrient present in it which helps in the growth performance of broilers. Present result can also be compared with [8] who found that Cassia fistula has positive effect on growth performance through increase in weight gain because of its biological properties such as its use as purgative, antioxidant and hepato-protective effects. Moreover, fruit of the plant is rich in vitamin $\mathrm{K}$, vitamin $\mathrm{C}$, calcium and minerals such as iron and magnesium.

\section{Feed intake}

Our results are in agreement with [9] who reported non-significant difference in feed intake after Cassia fistula supplementation. Moreover, our experimental results have 
shown significant difference that the control group. Additionally, our findings indicate that birds without Cassia fistula supplementation consumed more feed in comparison with birds supplemented with Cassia fistula. Contrarily to this [10] has reported that Cassia fistula contains maximum amount of nutrients which are generally required for the growth performance of bird and thus birds consume less feed.

\section{FCR}

Our results are similar to the findings of [11] who reported that dietary inclusion of $2 \mathrm{~g} / \mathrm{kg}$ Cassia improved feed conversion ratio significantly and suggested that it can be used as alternative to antibiotic growth promoters in broilers. Our Current results are comparable with [12] who reported that supplementation of Cassia at the dose of 5\% in broiler diet enhanced the FCR (1.8) in comparison to the control group (2.0). In another study conducted by [13] reported that supplementation of herbs as a feed additive resulted in better FCR. Moreover, the feed conversion ratio improved due to the increased absorption of nutrients and better digestion [13].

\section{Dressing percentage}

In addition to this our results indicated birds supplemented with Cassia fistula resulted highest dressing percentage in comparison with birds without Cassia fistula. Our current results are in agreement with [14] who reported that no significant difference in dressing percentage was observed when Cassia fistula leaf meal was supplemented to broiler. Our findings are also in line with [15], who reported that dressing percentage is related with weight, whenever weight is increased the carcass percentage also increases. Furthermore, present results are in accordance with [4] who reported that Cassia fistula when incorporated in broiler feedings has positive effect on dressing percentages.

\section{Mortality percentage}

Our results indicated that birds without Cassia fistula supplementation resulted higher mortality percentage in comparison with birds supplemented with Cassia fistula. Thus, our results are in agreement with [16], who reported that it has positive effect on growth performance by decreasing the mortality rate as Cassia fistula possessed the diverse biological activity such as antiinflammatory, antipyretic, laxative and useful in skin diseases, gouty arthritis, ulcers, carbuncles, intermittent fever, boils rheumatologic and antimicrobial activity which collectively decreases mortality rate in broilers. Our findings are also in agreement with [16], who reported that Cassia fistula has immense biological properties which have positive effect on growth performance that decreases mortality rate and improves digestibility and its root is prescribed as a tonic, astringent and strong purgative.

\section{Relative weight of organs (\%)}

We have also reported that there is marked difference in the relative weight of heart and spleen after feeding. Our present findings are in partially agreement with [17], who reported no significant difference in the relative weight of internal organs of birds which were fed with different levels of supplementation of Cassia leaves in diet. Thus, our findings are in similarity with [18] who reported that feeding the Cassia fistula have positive effect on, heart and spleen of broiler, but no effect was observed in liver and gizzard weight.

\section{Conclusion}

It was concluded that Cassia fistula@250 $\mathrm{mg} / \mathrm{kg}$ (group-E) supplementation in broiler ration showed optimum results in terms of growth performance and health of commercial broiler such as Weight gain, Feed intake, Feed conversion ratio (FCR), Dressing \%, Mortality (\%) and weight of non-edible organ. 


\section{Authors' contributions}

Conceived and designed the experiments: SA Depar, IH Lighari, N Rajput \& MN Rajput, Performed the experiments: SA Depar, AG Soomro, AA Moryani , MQ Mazari, \& TR Bheermani, Analyzed the data: SA Depar, MB Arain, MA Memon \& C Wajid, Contributed materials/ analysis/ tools: $\mathrm{SH}$ Depar, S Tunio, \& MA Memon, Wrote the paper: IH Lighari.

\section{Acknowledgements}

The authors are grateful to the team of Department of Poultry Husbandry, Faculty of Animal Husbandry and Veterinary Sciences, Sindh Agriculture University, Tandojam for providing necessary infrastructure and resources to accomplish my research work.

\section{References}

1. Samy RP, Ignacimuthu $\mathrm{S} \&$ Sen $A$ (2004). Screening of 34 Indian medicinal plants for antibacterial properties. $J$ Ethnopharmacol 62(2): 173-181.

2. Cook RH, \& Bird FH (1973). Duodenal villus area and epithelial cellular migration in conventional and germ-free chicks. Poult Sci 52(6): 2276-2280.

3. Guo F, Kwakkel R, \& Verstegen M (2000). The use of Chinese herbs as alternative for growth promoters in broiler diets. in Proceedings of the 21st World's Poultry Congress, Montreal, Canada.

4. Bhattacharyya DA (2011). comparative study on the antioxidant and antimicrobial properties of garlic and coriander on chicken sausage. Int $J$ Meat Sci (2): 108-116.

5. Sang-Oh P, Chae-Min R, Byung-Sung $\mathrm{P}$ \& Jong H (2013). The meat quality and growth performance in broiler chickens fed diet with cinnamon powder. J of Envi Bio 34(1): 127.

6. Adebayo O, Fagbenro $\mathrm{O} \&$ Jegede $\mathrm{T}$ (2004). Evaluation of Cassia fistula meal as a replacement for soybean meal in practical diets of Oreochromis niloticus fingerlings. Aqua. Nutrit 10(2): 99-104.

7. Ansari JZ, Haq A, Yousaf M, Ahmad T, \& Khan S (2008). Evaluation of different medicinal plants as growth promoters for broiler chicks. Sarhad J Agri 24(2): 323329.

8. Panda SK, Padhi L \& Mohanty G (2011). Antibacterial activities and phytochemical analysis of Cassia fistula (Linn.) leaf. J Adv Pharm Technol 2(1): 62.

9. Ayssiwede SB, Chrysostome C, Ossebi W, Dieng A, Hornick JL \& Missohou A (2010). Digestibility and metabolic utilisation and nutritional value of Cassia tora (Linn.) leaves meal incorporated in the diets of indigenous Senegal chickens. Rev de Medec Veter 161(12): 549-558.

10. Makkar $\mathrm{H}$, Francis $\mathrm{G}$, \& Becker $\mathrm{K}$ (2007). Bioactivity of phytochemicals in some lesser-known plants and their effects and potential applications in livestock and aquaculture production systems. Anim J 1(9): 1371-1391.

11. Toghyani M, Toghyani M, Gheisari A, Ghalamkari G \& Eghbalsaied S (2011). Evaluation of cinnamon and garlic as antibiotic growth promoter substitutions on performance, immune responses, serum biochemical and haematological parameters in broiler chicks. Lives. Sci 138(1-3): 167-173.

12. Rafeeq M, Rashid N, Tariq MM, Tareen RB, Ullah A, \& Mustafa Z (2017). Evaluation of Alternatives to Antibiotic Feed Additives in Broiler Production. Pak J of Zool 49(3).

13. Kabir S, (2009). The role of probiotics in the poultry industry. Int J Mol Sci 10(8): 3531-3546.

14. Ayssiwede SB, Missoko-Mabeki R, Mankor A, Dieng A, Houinato MR, Chrysostome CAM, \& Hornick JL (2012). Effects of Cassia tora (Linn.) 
leaves meal inclusion in the diet on growth performances, carcass and organs characteristics and economic margins in growing indigenous Senegal chickens. Rev de Med Veter 163(8/9): 375-386.

15. Singh $P \&$ Karnwal $P$ (2006). Antifungal activity of Cassia fistula leaf extract against Candida albicans. Ind $J$ Microbiol 46(2): 169.

16. Pawar AV, Patil SJ \& Killedar SG (2017). Uses of Cassia fistula Linn. as a Medicinal Plant. Int J of Adv Res and Develop 2(3): 85-91.
17. Zanu HK, Asiedu P, Tampuori M, Abada M, \& Asante I (2012). Possibilities of using Moringa (Moringa oleifera) leaf meal as a partial substitute for fishmeal in broiler chickens diets. Onl J of Ani and Feed Res 2(1): 70-75

18. Pradeep K, Mohan CVR, Gobianand K \& Karthikeyan S (2007). Effect of Cassia fistula Linn. leaf extract on diethylnitrosamine induced hepatic injury in rats. Chemico Biol Interactions 167(1): 12-18. 